\title{
Turtle, the Mysterious of the Sky
}

Wael Sayed Soliman*

Faculty of Tourism and Hotel Management, Helwan University, Egypt

\section{ARTICLE INFO}

Keywords:

Turtle

Decan

Constellation

Nut

Zodiac.

\begin{abstract}
Turtle was not a sacred animal to the Egyptians, but it occupied an important part of the scenery art in Ancient Egypt. It dwelled the sky by the Early New Kingdom, and acquired a traditional shape represent the animal form itself and forms widespread renovations in the Late and Greco-Roman Periods. This study identifies the specific source for the turtle figures on some distinctive astronomical scenes, shown a complete relation with the depictions of such animal and its consequence in these kinds of scenes; while the best examples of turtle figures have been found on the ceiling of the temples, tombs, inner side of some sarcophagi's lids, galleries, water clock and others. It occupied an important part on the ancient Egyptian astronomical scenes, as a constellation and then one of the 36 decans, and always shown in its natural figurine, without any mythological features (wings, human bodies, other animal bodies, etc.) like many other animals-creatures.
\end{abstract}

(C2020 Faculty of Tourism and Hotels, Fayoum University All rights reserved

\section{Introduction}

The Ancient Egyptians were close observers of the heavenly bodies' behaviour from prehistoric times, which was evidenced by the numerous astronomical scenes and tools they left. Throughout Egyptian history, images of night sky decorated temples coffins, tombs, and some other different kinds of monuments. These images served as a theoretic and pictorial tribute to the solar cycle and bore strong renewing associations. This article investigates the function of the turtle within a various collection of ancient Egyptian astronomical scenes dating back to different periods, which was readily incorporated into the existing tradition of astronomical iconography. Though there was no actual evidence for turtle iconography found in ancient astronomical scenes before the New Kingdom, the researcher ample to prove that knowledge of those creatures existed from the earliest time and pervades the Egyptian symbolism.

Ancient Egyptian astronomical texts and scenes often contain star names and figures listed in order. Some of these stars are the decans which form decan lists with different families. The well-known element decan Stwy, which the ancient Egyptians named 'the two turtles' shown in the Egyptian documentation of the Middle Kingdom, with diagonal star clocks. While in the New Kingdom, Late Period, and the Greco-Roman Period, it displays on the ceilings of various temples like Deir el-Haggar, Dendara and Esna, also represented as diverse as royal and individuals' tombs, sarcophagi and other monuments. Among those special representations of the sky, that animal occupied a part in the common scene of the king spearing

\footnotetext{
* Contact Wael Sayed Soliman at: orioneg@hotmail.com
} 
Apophis as a turtle, which is usually accompanied by another which represents the destruction of figures of royal enemies by the chief lector priest in a ritual called: "Overthrowing the enemies of the king daily"(fig.8).

\section{Turtle}

Turtle, that special creature that gained a great respect among the ancient civilizations as both land and water creature, was depicted as a patient wise animal. Due to its crumpled appearance, strength, slow movement, and long lifespan, it is a sign of solidity, sedentary and longevity in many cultures (Cirlot, 2002). It also has an important role in mythologies around the world, concerning the origin of the Earth (Stookey, 2004), which carry it on its own shell. Turtle is among three great animals, in addition to serpent and elephant, which many civilizations believe that they may support Earth. Hindus consider that hemispherical Earth supported on the backs of four elephants, which stand on the hemispherical carapace of a massive tortoise floating on the surface of the world-waters (Kenton, 1928), which is the distinctive idea in both China and Japan ancient cultures (Becker, 1994). For Mayans, the Earth itself has the form of a circular domed of a turtle floating on the sea (Taube, 2012).

Bishop Isidore of Seville, during the $7^{\text {th }}$ Century AD. mentioned that turtle (testudo) is so called because its back is covered over with a shell (testa) in the manner of a vaulted roof, which for the ancestors would make the roofs of their temples in the shape of a tortoise shell (Bishop Isidore of Seville, 2006). These would be made thus to represent the image of the sky, which is evidently convex.

Today there are about 250 species with 11 families of turtles and tortoises worldwide (Rittner, 2004). It belongs to that class of cold-blooded vertebrate hibernation reptilian animals. There are four different kinds of turtles: river turtles, land turtles, sea turtles and mud turtles. The Egyptian turtles were commonly dwelled deserts, seacoasts, River Nile and its valley.

Among the three types of turtles that dwell in Egypt, are two Aquatic three-clawed types: Red Sea turtles (Chelonia Imbricata) and the freshwater

\footnotetext{
2 Many of the terrestrial turtles are called 'tortoises'.

3 For more information about the tortoise see: Christoph, S. and Willi, S. (2008). "The Egyptian
}

turtle Trionyx triunguis riverine fauna or Nile turtle. Its leathery carapace may have served as a shield at the very beginning of the First Dynasty (Fischer, 1966). The Trionyx is rarely encountered in the lower reaches of the Nile today, having moved southward to the less populated area of Nubia and Sudan (Fischer, 1968). The same kind also spread throughout the rivers of Africa. Its colour is olive or olive-brown, with dark-rimmed white dots on the shell (Fischer, 1968). One of its main features is the long tubular nose that protrudes above the water when it breaths (Carr, 1952). It also submerges for a long time, ten hours at a time under the water; it prefers the darkness of the shallow depths of the river.

While the land tortoise ${ }^{2}$ Testudo kleinmanni, is this high-domed carapace turtle used by the Ancient Egyptian for sounding board for lutes in the New Kingdom (Fischer, 1966). Egyptian tortoises blend into their environment have a light coloration and this is because they live in sandy rocky areas. Loveridge and Williams (Loveridge, 1957) classified the Egyptian tortoise in 1957, as reptiles, their size and colour are perfect for the dry arid climates in the desert, light shelled tortoise can blend in and keep cool through the heat in the day ${ }^{3}$. The males' features are different from the females. The male Egyptian tortoises are smaller and have longer tails than the females.

It was not a sacred animal to the Egyptians, but it occupied an important part of the scenery art in Ancient Egypt. Museums around the world contain different kinds of collections, especially threedimensional figurines, side by side various scenes and texts which represent Egyptian turtles. The most popular figure regarding representations of the Egyptian turtles seems to be the freshwater turtle more than the desert tortoise. The body of the supposed glyph and art representations is a depressed oval, and the long neck, the features which are closer to turtles than tortoises. ${ }^{4}$

Shells of turtle were used widely in the form of cosmetic palettes, combs, rings, bracelets, amulets, dishes, knife hilts, bowls, and musical instruments (sounding boards for mandolins, harps, and lutes). They are made in the shape of the turtles, decorated by the figure of the animal itself, or even use its organs for making them. The flesh of Nile

Tortoise, Testudo kleinmanni Lortet, 1883 in Libya," Salamandra, vol.44, no.3, Rheinbach, pp.141-152.

${ }^{4}$ According to the figures and plates studied by the researcher in this article. 
Turtle was eaten by the earliest Egyptians from Predynastic times to the Old Kingdom. Trionychidae are enjoyed throughout the world for their excellent flavor, and that kind of meat is still eaten in Sudan (Durrell, 1953 and Fischer, 1966), and some other African countries.

But later during the Middle Kingdom that item of Egyptian diet evidently fell under a curious forbidding, the matter that needs some clarification. Starting from this period, turtle itself also began to be considered "filth of Ra" and the role turtles became an evil one. It seems that the actual reasons were because the animal is a kind of flesh-eater and grows to a formidable a size that is capable of imposing serious wounds if not handled with great respect (Fischer, 1966). It could be because an outbreak of salmonellosis ${ }^{5}$ was traced to the Nile Turtle during that time.

Turtles were used only for medical purposes (Veiga, 2009) during the Middle Kingdom, unfortunately the medical texts do not identify the animal's habitat, whether Trionyx or Testudo (Deines, 1959). At that time, they used both the internal organs and shell for magical purposes. While during the Greco-Roman Period similarly turtles were disdained as food but also used various parts of it for medicine (Keller, 1913).

In Ancient Egypt, there was a generic word for turtle which is a Styw 'tortoise'. ${ }^{6}$ There are also other wide range of words identify that animal like: $\$$; var. 口 Stw 'turtle ${ }^{77}$. The word is probably derived from StA 'secret, hidden, or mysterious', ${ }^{8}$ referring to the vanishing of turtle under the water of the river and being hidden in the mud (Walle, 1953). Faulkner suggests that the word comes from the same root ST 'tortoise' to cover oneself up (to hide or to make secret) like a tortoise (Faulkner, 1977). During the Greco-Roman Period, the word $S t A^{9}$ was also used to identify a specific offering rite 'slaying of the

\footnotetext{
${ }^{5}$ For more information see: Mitchell, A. and Simon M. S. (January 2001). "Salmonella in Reptiles Mark," Seminars in Avian and Exotic Pet Medicine, vol.10, no.1, Philadelphia, pp 25-35.

${ }^{6} \mathrm{ME}$, p.273; $\mathrm{Wb} I \mathrm{~V}, \mathrm{p} .556$.

${ }^{7} \mathrm{~Wb} \mathrm{IV}, \mathrm{p} .557$.

${ }^{8} \mathrm{~Wb} I V$, p.272, $M E$, p. $272 ; L E$, p. 138 .

${ }^{9} P L$, p.1134.

${ }^{10} L E$, vol.2, p.138.

${ }^{1} P L$, p. 1034.
}

turtle' where the king is represented spearing the creature. In general, both Stw and StA might have the meaning of "mysterious one".

Turtle appeared in the Coffin Texts as Stw in the (spell 368) reads: "if you tell me to eat this, then Ra will eat turtles" (De Buck, 1961). This negative position text displays the importance of the turtle's flesh to protect the deceased from having to eat excrement in the Underworld. The determinative at the end of the word shows that the Ancient Egyptians classified the animal as a kind of fish. It seems that it is because Trionyx is an inhabitant of the aquatic environment that has a soft shell, so the ancient Egyptians integrated it into fish, just like the crocodile.

Both the two words StA and alongside Stw to identify the animal during the Late Period (Kitchen, 1993) ${ }^{10}$, while in the GrecoRoman Period they kept using 2 (Cauville, 2001); var. 2 , 口 11 , \& StA ${ }^{11}$ 'turtle.' It seems that by the beginning of the Middle Kingdom, when the disagreement between the turtle and the sun god Ra had greatly increased, its name Stw was written as to mean "the mysterious one" StA.

There are likewise different other names used by

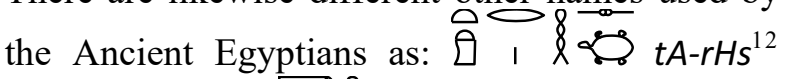

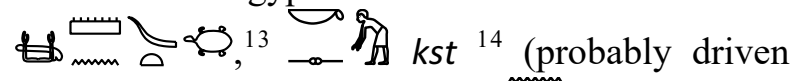
from $k s i$ 'to bow down'), ${ }^{15} \Delta \circ \Omega_{n q t^{16}}$ गु $-\infty$ \&ns 'Heavy one, ${ }^{17}$ due to it could be a destructive beast and $d n s^{18}$ implies its power and

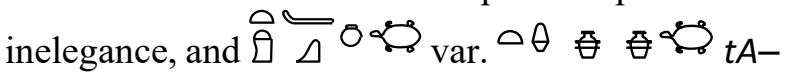
Hnqt var. $t A-H q t$ is a general term for provisions, from at least the $5^{\text {th }}$ Dynasty. It continues to be so popular practice during the Greco-Roman Period in the so called 'Killing the turtle' texts. The name $t A-$ Hnqt was used for the turtle as a pun, which reads

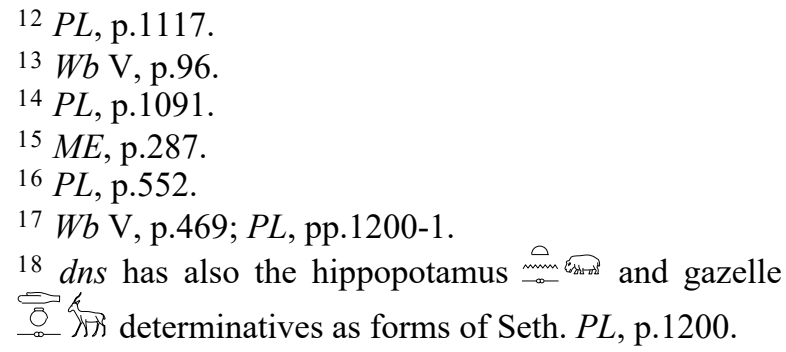


as 'Presenting bread and beer'. The slaying of the Sethian dangerous turtle seems to be symbolic for the king offering the gods the basic requirements of life - bread and beer (Walle, 1953 and Delvaux, 2014). ${ }^{19}$

Finally, 政 'turtle, ${ }^{\prime 20}$ which is simply driven from the word mm \& $\mathbb{C}_{m n H}$ 'papyrus; ${ }^{\prime 21}$ refers to one of its main zoological features as one of the papyrus swamp dwellers. In Kom Ombo temple the word Stw reads as with the determinative of the papyrus plant, while in Esna the plant itself appears as

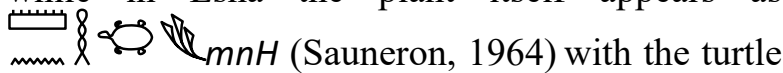
determinative, which shows the clear relation between both. Regardless of it as an offering, nevertheless a big number of carapaces were found in the great ceremonial complex at Heirakonpolis (Friedman, 2011), suggests that it played a role ceremonial ritual in Ancient Egypt. The earliest representations of the turtle date back to Predynastic times in the form of slate palettes ${ }^{22}$, amulets, vessels, stone vases (Anderson, 1898) and other objects represent different depictions of the turtles. Other art representations of turtles in tombs and temples were not much common.

Kadish shows that after Middle Kingdom representations of turtles are more often found on amuletic objects and furniture (Kadish, 1968). While during Middle Kingdom, the turtle's shape is very rarely related to any object which would come into close contact with a person, a fact which reflects the increasing clear aggression shown to turtles in texts and scenes.

The tombs of the Old Kingdom till the early New Kingdom contain scenes of daily life rarely representing turtles belonged to fish-class being caught by net, hook, or spear. It appeared during the Late Old Kingdom in a relief from the sun temple of Neuserre (fig. 1), ${ }^{23}$ and in some daily life scenes of the private tombs. An unexpected number of examples are driven from the New Kingdom. It is depicted as a harmless reptile, but later starting from the $19^{\text {th }}$ Dynasty till the Greco-Roman Period,

${ }^{19}$ PL, p.1117.

${ }^{20} P L$, p.1076. The term is used in turtle slaying rituals.

Walle suggested that $m n H$ was driven from $i m n H$ 'to butcher.' Walle, B. Van de, p.185.

${ }^{21} M E$, p. 109.

22 The turtle-shaped palettes appear in the middle Predynastic phase (Naqada II). Kathryn A. B. (1999). usually depicted as an evil creature associated with Apophis (figs.8-10).

\section{Figure 1}

A relief from the temple of Neuserre, Metropolitan Museum of Art

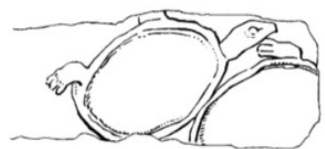

After Fischer, H.G. Ancient Egyptian representation of turtles, fig.4a

\section{Astronomical Iconography}

Turtle has a great variety of symbolic meanings derived from the consideration that these meanings may relate either to the turtle as a whole or to any of its major characteristics. The primary characteristics that gave the turtle its symbolic significance was the special place it occupies in the animal kingdom. In some Ancient civilizations like India, China and Japan, turtles played a big role as cosmic supporter of the universe (Haynes, 2000 and Kelley, 2011). The ancient Chinese Turtle constellation was among others namely the sword, the snake, and the big dipper, they formed a cross shape with the ecliptic pole at its center (Maeder, 2011). Commonly, it was a symbol of wisdom, skill, fertility, and power, in addition, its back shell is regarded as a symbol of the vault of heaven (Becker, 1994).

To understand the conditions under which the iconography of the turtle was incorporated into Egyptian collection of astronomical imagery, it is necessary to first outline the history, use and meaning of representations of heavenly bodies in Egypt. From the Old Kingdom onward, representations of celestial bodies are included in the decoration of temples, tombs, coffins, etc. The ritually charged contexts in which astronomical images appear suggest that they function as more than mere representations of the natural world (Stewart, 2010).

The Ancient Egyptian representation of the Turtle astral-body is closer to the certain Arab representation of the Tortoise constellation, the so

\footnotetext{
"Armant," Encyclopedia of Archaeology of Ancient Egypt, Routledge, London, p.163.

23 The fragment is in the Metropolitan Museum of Art E.726, and published by Fischer, H. G. Ancient Egyptian representation of turtles, fig.4a.
} 
called 'Lyra constellation,' refers to the musical instrument, which illustrated by $10^{\text {th }}$ century Arab astronomer Abd el-Rahman Al-Sûfi in his FixedStars Catalogue (as on contemporary celestial globes) as a Sulahfat or tortoise (fig. 2$)^{24}$. Isidore (Vivian, 1923 and Bishop Isidore of Seville, 2006) mentions a Greek legend tells us that Mercury invented it: "he found the body of a tortoise cast up by the Nile and discovered that by striking the sinews after the flesh was consumed a musical note was obtained. He made a lyre of similar shape, having three strings, and gave it to Orpheus, the son of Calliope, who by its music enchanted the beasts, birds and rocks." Another point of view created by Lull and Belmonte (Lull, 2006 and Lull, 2009), who believed that the two turtles star may be identified with the two bright stars of Canis Minor, Procyon and Gomeisa.

\section{Figure .2}

Sulahfat constellation, according to Al-Sûfi in his Fixed-Stars Catalogue

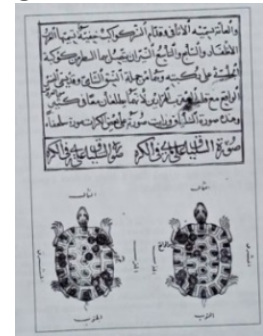

After Ihsan, H. Abd al-Rahman al-Sufi and his book of the fixed stars, fig. 37 .

Many texts from the New Kingdom onwards refer to enormous cosmic deities whose head and hands move about in the sky, and whose feet on earth or within the underworld (Darnell, 2004). Perhaps the closest similarity is the Greco-Roman Period famous depiction of a cosmic tortoise from Kom Ombo, whose body lies under the cultivated region of Egypt, carrying the desert regions of the four cardinal directions upon his arms and legs (Gutbub, 1979 and Klotz, 2020). A Hymn to Sobek reads as: "It is the earth stable for the banks (description of the body of the turtle), these red deserts at the end of its four limbs, it is Geb, great god, whose image is the turtle (tA-Hnqt) which pours out the flood in its time that fertilizes arable land" (De Morgan,

24 As seen in his manuscript MS 5063. For more information see: Ihsan, H. Abd al-Rahman al-Sufi and his book of the fixed stars: a journey of re-discovery, Ph.D. Thesis, James Cook University, 2010.
1895 and Guilhou, 2016). The turtle is shown in a more favourable light, where it is connected with the source of the Nile and has positive aspects as a water creature.

A statue of a tortoise (fig. 3$)^{25}$ was used as a votive Mehen Game with unusal carapace shows series of concentric circles with straight lines radiating from the center resembling the hieroglyph for 'star' $\chi$ The same motif appeared in another statue mentioned by Fischer (Fischer, 1968). This may allude to the astronomical aspect of the turtle that is attested by a constellation identified as twin turtles (Fischer, 1968). The star in question is to identify Goddess Bat (touch the ears, horns and the crown of her head) (Fischer, 1968) or as Sirius Constellation. The majority depictions have their backs embellished with, like crossed-network stippled (realistically to the nature of the animal), and as longitudinal lines pattern, but that astral design did not appear in a single monument.
Figure .3

Statue of a Turtle

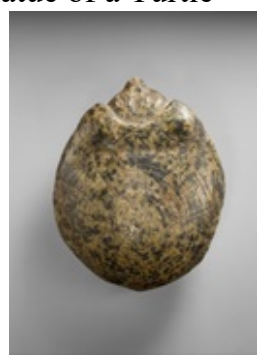

cf. Metropolitan Museum of Art Online

\section{Figure 4}

The radiated tortoise Astrochelys Radiata

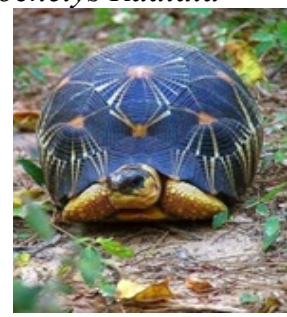

cf.https://www.reddit.com/r/pi cs/comments/

$87 \mathrm{jd} 9 \mathrm{p} /$ radiated_tortoise_of madagascar/
This kind of radiated tortoise Astrochelys Radiata, its carapace has a pattern of radiating lines imitating the stars (fig.4), is a dweller of the forests and woodlands of southern Madagascar ${ }^{26}$. It is a distance of $5354 \mathrm{kms}$. between the two countries, which makes it hard to accept this kind of tortoise as an Egyptian animal inhabitant. So, it is suggested that this star is just a matter of astronomical insignia, showing the importance of the animal as one of the dwellers of the sky.

Turtles were among many kinds of animals that populated the skies of Ancient Egypt for thousands

25 It is found at Luxor and dated back to the Early Dynastic. It is now in the Metropolitan Museum of Art E.61.33.

${ }^{26}$ For more information see: Kirkpatrick, D. T. Radiated Tortoise, Reptile and Amphibian Magazine, Pennsylvania, Mars/April 1992, pp.18-24. 
of years. Among all the features, turtles appeared only as Decan, Constellation and finally as part of religious scenes. They include New Kingdom ceilings in royal and private tombs and in a few temples, as well as the inner side of some sarcophagi's lids; and many Greco-Roman Periods, such as ceilings, sarcophagi, galleries, temples, water clock and others.

A few numbers of monuments with astronomical features in their design are known from ancient Egypt. The characteristic features of astronomical representations are the presence of all the following elements: group of Constellations, attendant deities, Decans, Planets, Calendric elements (lunar and solar), Signs of the zodiac, hours of the day and night, some other cosmic deities (like Geb, Nut, etc.), figures from the Book of the Night, the four winds and finally Deities of the Epact.

It occupied a part on twenty-seven masterpieces of ancient Egyptian astronomical scenes, starting with

27 The temple is located at the western bank of Luxor city. It is dated back to the $19^{\text {th }}$ Dynasty, reign of the king Ramsses II. The astronomical scene (A) on the ceiling of the axis aisle of the Second Hypostyle Hall; it consists of the Northern constellations, Lunar Calendar, decans, and the planets. While scene (B) on the inner face of the architrave north of the central aisle of the Third Hypostyle Hall; it consists of decans and planets. For more information see: Parker, R. A. The Calendars of Ancient Egypt, Studies in Ancient Oriental Civilization, no.26, Oriental Institute of the University of Chicago, Chicago, 1950, pl.III, EAT III, pp.17-18. This astronomical scene (C) is located on the inner face of the architrave north of the central aisle of the Third Hypostyle Hall; it consists of decans and planets. For more information see: EAT III, pp.20-1.

28 It is the temple of Khnum at Esna which dated back to the Greco-Roman Period. The rectangular zodiac is decorating six of the seven bands of the Hypostyle Hall ceiling which built by Vespasian-Domitian (69-96 A.D.). The zodiac on the ceiling is framed at either end by a bending figure of Nut; it consists of the zodiacal constellations, some other constellations, decans and the planets. For more information see: Sauneran, S. Le Temple d' Esna: tome 4, IFAO, Le Caire, 1969, no.418; EAT III, pp.82-83; PM 6, p.116.

29 The temple is located at the western end of the Dekhleh Oasis. It is dated back to the $1^{\text {st }}$ Century A.D. The astronomical scene itself which dated back to the $2^{\text {nd }}$ Century A.D. is decorating the ceiling of the sancturary. The zodiac is represnting a bending figure of Nut, between her arms and legs there are four registers of scenes, contain decans, days of the lunar months, the nightly course of the sun from the west to the east and only six hours of the Night, the months of the astronomical ceiling of the tomb of Senenmut and ended by a wider variety scene dating back to the Ptolemaic and Roman Periods, will be used as the reference frameworks where my study will be outlined. Turtles are always shown in their natural appearance, without any mythological features (wings, human bodies, other animal bodies, etc.) like many other animals-creatures, serpents for example. The monuments on which the turtles are appear as a part of the astronomical scenes; I list as far as possible chronologically as follows:

\section{I- Temples:}

1. Ramesseum A (pl.1.1), B (pl.1.2), ${ }^{27}$

2. Esna (pl.1.3), ${ }^{28}$

3. Deir el-Haggar (pl.1.4), ${ }^{29}$

4. Dendera (pl.1.5). ${ }^{30}$

II-Tombs:

1. Senenmut (pl.1.6), ${ }^{31}$

2. Seti I (pl.1.7), ${ }^{32}$

the lunar calendar, the winds, and constellations. For more information see: Kaper, O.E. "The astronomical ceiling of Deir el-Haggar in the Dakhleh Oasis," JEA, vol.81, Egypt Exploration Society, London, 1995, p. $175 \mathrm{f}$.

${ }^{30}$ It is the temple of Hathor at Dendera which dated back to the Greco-Roman Period. The astronomical scene itself which dated back to late Ptolemaic Period is decorating the west half ceiling of the inner room of of the West Osiris Chaple on the roof. The centre of the ceiling was occupied by a bending figure of Nut with feet and hands touching the ground, under her body is the astronomical scene which representing the Lunar staircases, and both Orion and Sirius constellations. For more information see: Brugsch, $\mathrm{H}$. Thesaurus Inscriptionum Aegyptiacarum, band 1: "Astronomische und Astrologische Inschriften Altaegyptischer, Dnkmaeler." J.C. Hinrich' Sche Buchhanlung, Leipzig, 1883, pp.62-3; Derchain, P. "La Pêche de L'oeil et les Mystères d'Osiris a Dendara," $R d E$, tome 15, Paris, 1963, p.24.

${ }^{31}$ It is the unfinished tomb of Senenmut at Deir elBahari in the west bank of Luxor city, dated back to the $18^{\text {th }}$ Dynasty. The astronomical scene is located on the ceiling of the chamber. The decans is on the south half, running from east to west. The northern constellations and lunar calendar are occupying the other half of the ceiling. For more information see: PM I, p.418; EAT I, p.22; EAT III, pp.10-12; Dorman, P. The tombs of Senenmut- the Architecture and Decoration of tombs 71 and 353, Metropolitan Museum of Art, New York, 1991, pp.138-146.

32 It is the tomb of king Seti I in the Valley of the Kings, dated back to the $19^{\text {th }}$ Dynasty. The astronomical scene decorated the vaulted ceiling of Hall $\mathrm{K}$. The decan list 
3. Mernptah (pl.1.8), ${ }^{33}$

4. Tausert and Sethnakht A (pl.1.9), and B $(\mathrm{pl} .1 .10){ }^{34}$

5. Ramsses VI A (pl.2.1), B (pl.2.2), C (pl.2.3), D (pl.2.4) and $\mathrm{E}(\mathrm{pl} .2 .5){ }^{35}$

6. Ramsses VII A and B (pl.2.6), ${ }^{36}$

7. Ramsses IX A and B (pl.7), ${ }^{37}$

is on the south half, running from west to east; and the northern constellations take up the north half. The tops of the two halves are separated by a broad band along the north half. For more information see: PM I, 2, pp. 542-43; EAT III, pp.14-16.

33 It is the tomb of king Mernptah in the Valley of the Kings, dated back to the $19^{\text {th }}$ Dynasty. The astronomical scene decorated the vaulted ceiling of Hall J. It consists of the Northern constellations, decans and the planets. For more information see: PM I, 2, p. 509; EAT III, p.22.

${ }^{34}$ It is the tomb of Queen Tausert in the Valley of the Kings and intended later by king Setnakht. It is dated back to the $19^{\text {th }}$ Dynasty. The astronomical scene (A) decorated the vaulted ceiling of Hall $\mathrm{J}$, while scene (B) on Hall L. Each consists of decan lists, planets, northern constellations and deities. For more information see: PM I, 2, pp. 531; EAT III, pp.23-24.

35 This tomb started by king Ramsses $\mathrm{V}$ and finished by king Ramsses VI in the Valley of the Kings, dated back to the $20^{\text {th }}$ Dynasty. The astronomical scene (A) decorated the ceiling of corridor A, scene (B) decorated the ceiling of Hall E - south section, scene (C) decorated the ceiling of corridor $\mathrm{B}$, and scene (D) decorated the ceiling of Hall E - north section, scene (E) decorated the right and left walls of Room J. The scenes are consisting of poorly preserved decan list, planets, northern constellations, deities and Star clock table. For more information see: Brugsch, H. p.125 B; PM I, 2, pp. 512-4; EAT III, pp.29-33.

36 It is the tomb of king Ramsses VII in the Valley of the Kings, dated back to the $20^{\text {th }}$ Dynasty. The astronomical scene (A) decorated the south half of vaulted ceiling of Hall $B$, while scene (B) decorated north half of vaulted ceiling of Hall $B$. Both scenes are consisting of decan list, northern constellation and deities. For more information see: Brugsch, H. pp.126; $P M$ I, 2, p.496; EAT III, pp.34-6.

${ }^{37}$ It is the tomb of king Ramsses IX in the Valley of the Kings, dated back to the $20^{\text {th }}$ Dynasty. The astronomical scenes decorated the south and north halves of Corridor B ceiling. They are consisting of decan list, planets, northern constellations and deities. For more information see: PM I, 2, pp.502-3; EAT III, pp.36-38.

38 The cut rock tomb (TT223) of the priest Karakhamun in the South Asasif Necropolis, west bank of Luxor city, is dated back to the $25^{\text {th }}$ Dynasty. The astronomical scene decorated the ceiling of the burial chamber. It consists of decan list, planets, northern constellations
8. Karakhamun (pl.8), ${ }^{38}$

9. Pedamenope (pl.3.1), ${ }^{39}$

10. Montuemhat (pl.3.2),

11. Ibi (p1.3.3),

12. Petosiris (pl.3.4) ${ }^{42}$

III- Coffins:

1. Psusennes (pl.3.5), ${ }^{43}$

and deities. The centre of the ceiling was occupied by figure of Nut. For more information see: Polo, M. "A Bright Night Sky over Karakhamun: the Astronomical ceiling of the main burial chamber in TT 223," In: Pischikova, E. Tombs of South Asasif Necropolis, Thebes, Karakhamun (TT 223) and Karabasken (TT 391) in the twenty-fifty Dynasty, The American University in Cairo Press, Cairo, 2014.

39 The cut rock tomb (TT33) of Pedamenope in Asasif Necropolis, west bank of Luxor city, is dated back to the $25^{\text {th }}-26^{\text {th }}$ Dynasty. The astronomical scene decorated the ceiling of the burial chamber. It consists of decan list, planets, northern constellations, and deities. The centre of the ceiling was occupied by figure of Nut. For more information see: PM I, 2, p.55; EAT III, pp.40-41.

40 The cut rock tomb (TT34) of Montuemhat in Asasif Necropolis, west bank of Luxor city, is dated back to the $26^{\text {th }}$ Dynasty. The astronomical scene decorated the ceiling of the burial chamber. It consists of decan list, planets, northern constellations and deities. The centre of the ceiling was occupied by figure of Nut. For more information see: PM I, 2, p.59; EAT III, pp.41-42.

41 The cut rock tomb (TT36) of Petamenophis in Asasif Necropolis, west bank of Luxor city, is dated back to the $26^{\text {th }}$ Dynasty. The astronomical scene decorated the ceiling of the burial chamber. It consists of decan list, planets, northern constellations and deities. The centre of the ceiling was occupied by figure of Nut. For more information see: Kuhlmann, K. P. Das grab des Ibi, Obergutsverwalters der Gottes-gemahlin des Amun (Thebanisches Grab Nr. 36), Mainz am Rhein: P. von Zabern, Kairo, 1983.

42 The cut rock tomb (now-destroyed) of the priest Petosiris near Atfih, is dated back to the Ptolemaic Period, c.150 BC. The astronomical scene is decorating the ceiling of the first chamber. It consists of incomplete decan list and planets, northern constellation and deities. The centre of the ceiling was occupied by a bending figure of Nut with feet and hands to the north, the back to the east west with head in the west. For more information see: Daressy, G. "Tombeau Ptolémaique à Atfieh," $A S A E$, vol.3, Cairo, 1902, pp.175-179.

43 The red granite sarcophagus of King Merenptah (19 ${ }^{\text {th }}$ Dynasty) and reused by King Psusennes (21 ${ }^{\text {st }}$ Dynasty), found in Tanis, and now in Cairo Museum (JE 6337B). The zodiac occupied the inner face of lid. It filled by the raised arms goddess Nut, surrounding with incomplete 
2. Nakhtnebef (pl.3.6), ${ }^{44}$

3. Abu Yasin (pl.3.7), ${ }^{45}$

4. Harendotes (pl.3.8), ${ }^{46}$

5. Kleopatra (fig.4.1), ${ }^{47}$

6. Seonsaos (pl.4.2),

decan list, planets, northern constellations and deities. For more information see: Montet, P. La nécropole royale de Tanis, vol. 2: Les constructions et le tombeau de Psousennès à Tanis, Jourde et Allard, Paris, 1951, pp.119-20; EAT III, pp.38-39.

44 The granite sarcophagus of Nekhtnebef the grandnephew of King Nekhtnebef, is dating back to the $30^{\text {th }}$ Dynasty, now in the British Museum (no.6705).

The zodiac is occupied the inner face of lid. It filled by the raised arms goddess Nut, surrounding with the decan list, planets, northern constellations and deities. For more information see: Lepsius, R. Die Chronologie der Aegypter, Nicolaische Buchhandlung, Berlin, 1849, pp.68-69, 89, 105; Brugsch, H. pp.137-43; Gundel, W. Dekane und Dekansternbilder: ein Beitrag zur Geschichte der Sternbilder der Kulturvölker, Studien der Bibliothek Warburg, Glückstadt and Hamburg, Darmstadt,1936, pl.9.

45 The bull sarcophagus from Kom Abu Yasin, and now in Cairo Museum (JE 86723), is dating back to the $30^{\text {th }}$ Dynasty. The zodiac is occupying the inner face of lid. It filled by the raised arms goddess Nut, surrounding with incomplete decan list, planets, moths, northern constellations and deities. For more information see: Abd el-Salam, A. "Rapport sur les fouilles du Service des Antiquités à Abou-Yassin (Charquieh)," Annales du Service des Antiquités de l'Égypte, tome 38, Le Caire, 1938, pp.609-22.

46 The no. 6678 coffin of high priest Harendotes is now in the British Museum, dated back to the early Ptolemaic Period, is remarkable for it's form and ornamentition, and for the numerous astronomical texts and pictures which are painted inside the cover.This zodiac is representing on the wooden inner coffin. In the center a figure of Nut with arms above head and Chapter 89 of the Book of the Dead on her body, around her are a decan list, planets, and some constellations are represented. For more information see: Budge, E. A. W. British Museum, Guide to the first and second Egyptians rooms, London, 1904, p.92; EAT III, pp.6162; PM I, pp.623-24.

47 The wooden coffin of the Kleopatra the daughter of Soter found in Sheikh Abd el-Qurna, west bank of Luxor, and now in the British Museum (no,6706), is dated back to the Early $2^{\text {nd }}$ Century A.D. The zodiac is occupied the inner face of upper section of the coffin. It contains zodiacal signs and hours of the day and night, surrounded the body of the raised arms Nut. For more information see: EAT III, pp.91-92. Riggs, C. The Beautiful Burial in Roman Egypt: Art, Identity and Funerary Religion, Oxford University Press, New York,

\author{
7. Petemenophis (fig.4.3), ${ }^{49}$ \\ 8. Heter (fig.4.4). ${ }^{50}$ \\ IV-Miscellaneous: \\ 1. Karnak Water Clock (pl.4.5),
}

2005, p.281; Riggs, C. "Archaism and Artistic Sources in Roman Egypt. The Coffins of the Soter Family and the Temple of Deir el-Medina," Bifao, tome 106, Institut français d'archéologie orientale, Le Caire, 2006, pp.316-317.

48 The wooden coffin of Sensaos the daughter of Soter and the sister of Petamenophis, found in Sheikh Abd elQurna, west bank of Luxor, is now in the Leiden Museum (M.75), dated back to 109 A.D. The zodiac is occupying the inner face of upper section of the coffin. It filled by the raised arms goddess Nut, surrounding with the zodiac, and the hours of the day and night. For more information see: EAT III, p.92; PM I.2, p.675.

${ }^{49}$ The wooden coffin of the Petemenophis, son of Soter found also in Sheikh Abd el-Qurna, west bank of Luxor, and now in the Louvre Museum (no. E13048), is dated back to the Early $2^{\text {nd }}$ Century A.D. The zodiac scene occupied the inner face of upper section of the coffin. It contains zodiacal signs and hours of the day and night, surrounded the body of the raised arms Nut. For more information see: EAT III, pp.92-93; Riggs, C. The Beautiful Burial in Roman Egypt, pp.282-83. Riggs, C. "Archaism and Artistic Sources in Roman Egypt," pp.316-317.

${ }^{50}$ It is the wooden coffin of Heter probably from Thebes but now lost. It dated back to about 125 A.D. The zodical scene is on the inner face of upper section of the coffin. It represents the goddess Nut surrounding with zodiacal signs, horoscope, constellations, planets, hours of the day and night, and winds. For more information see: Brugsch, H. "Ueber ein neu entdecktes astronomisches Denkmal aus der thebanischen Nekropolis," Z̈̈S, band 14, Leipzig, 1880, p.21; EAT III, p.93; $P M$ I, p.647

${ }^{51}$ It was found broken in pieces at Karnak Temple in 1904 by Legrain and restored for the Cairo Museum. It is now at the Cairo Museum (JE 4940). It is dated back to the $18^{\text {th }}$ Dynasty, reign of Amenhotep III. The outer surface of this clock is decorated with many astronomical scenes (Decan list, planets, lunar calendar, northern constellation and deities) and other different religious scenes in three registers. For more information see: Borchardt, L. "Die Altägyptische Zeitmessung," Die Geschichte der Zeitmessung und ser Uhren, band 1, Berlin, 1920, p.13f.; Sloley, R. W. "Primitive Methods of Measuring time," JEA, vol.17, The Egypt Exploration Society, London, 1931, p.174; Macnoughtan, B. A scheme of Egyptian chronology, Luzac and Co., London, 1932, pp.221-6; Pogo, A. "Egyptian water clock," Isis, vol. 25, Brussels, 1936, p.40; Leblance, Ch. et Nelson, M. "Le Clepsedre de 
2. Roda Nilometer (pl.4.6), ${ }^{52}$

3. Hermopolis A and B (pl.4.7). ${ }^{53}$

Identifying the correlations between all of those monuments reveals the kind of copies and adaptations of much earlier texts and scenes came about. The function of turtle imagery is supported by its incorporation into monuments decoration from the New Kingdom until the Greco-Roman period. For instance, the relative figures of the turtles in the zodiac are not in big touchable different from one astronomical scene to another. It should be noted that the motif itself was but one of many competing motifs in a varied Greco-Roman zodiacs and other monuments. From the above indicative examples, it can be seen that Egyptian iconography was utilized in peculiar ways during this late period, often infused with non-Egyptian iconographical elements. There also seems to be less prevalence of ancient Egyptian iconography, which is a ramification of the extensive Greek and Roman presence in Egypt at the time.

\section{Constellation or Decans}

Each of the early civilizations, especially the Egyptians, grouped the stars into various constellations. The glyphs of the constellations vary in number and shape from one monument to another. The whole known main Egyptian constellations are divided into two main groups: Northern and Southern. The last group was essentially formed by a belt of constellations known as 'Decans'. Some archaeologists like for example, Guilhou suggests that Stwy the Tortoise

Karnak," Catalouge de l'exposiyion: Ramses le Grand, Paris, 1976, p.139.

52 It is a ceiling block reused in the Nilometer at Roda, with the original location is unknown, dated back to the $26^{\text {th }}$ Dynasty. The astronomical scene is a part of end of decan list and planets. For more information see: EAT III, pp.48-9.

${ }^{53}$ The astronomical scene (A) is on the ceiling of a chapel within the subterranean Gallery $\mathrm{C}$ at Tuna elGebel (Hermopolis west), on west side beyond the arch. While, the scene (B) decorated the ceiling of niche G$\mathrm{C} \mathrm{B} / 2$ in east side of Gallery $\mathrm{C}$ near entrance. Both are dated back to the reign of the king Ptolemy I. The zodiacs is containing a decanal list, planets, north constellation and dieties, around a figure of stretch Nut. There is not any survived picture for the badly rubbed ceiling, but Parker depended on the information of Caminos in 1964. For more information see: Gabra, S. "Fouilles de 1' univeriste Fouad El Awel a Tuna El- constellation (Turtles pair) started its own appearing on the monuments as a constellation in the Southern Sky, and then became one of the 36 decans (triangle decan) (Guilhou, 2016). But I think that is pure decan, especially because its regular position between decans nor constellations according to all those evidences.

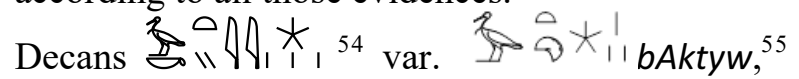
the term could be derived from $b A k$ 'servant', ${ }^{56}$ if the stars were seen as servants of the sun and moon. They are thirty-six stars formed the southern group belt, constellations, ${ }^{57}$ or subdivisions of constellations (Toomer, 1972 and Relek, 2003), rising at particular hours of night. Each one is rising heliacally for 10 days apart and invisible for 70 days. Each period of 10 days was marked by the heliacal rising of the next decan (Sloley, 1934 and Antoniadi, 1934), which was used for timekeeping. This group of stars mentioned in the oldest literary evidence for Egyptian astronomical thought and, in fact, the oldest surviving example of Egyptian funerary texts, are the Pyramid Texts, ${ }^{58}$ which likely represent the classification of an earlier oral funerary tradition; and in the diagonal star clocks decorated the coffin lids of the Middle Kingdom. It occupied a clear part of many other monuments right down till the Greco-Roman Period. Decan can be represented by one or more of the following elements: figure, deity and decanal stars (single star, number of stars or dot symbols). The diagonal star clocks had a special set of "triangle" decans for the Epagomenal Days, twelve in number which we should expect to find in some

Gebel", $A S A E$, tome 39, Le Caire, 1939, p.491-92; EAT III, pp.54-5 and 58-9.

${ }^{54} \mathrm{~Wb}$ I, p.430.

${ }_{55}$ PL, p.304.

56 ME, p.79.

57 Actually, most of writers before 1945, considered these decans as constellations, like Daressy and Petrie: Daressy, G. "Une ancient liste de decans Égyptiens," ASAE, tome1, Le Caire, 1900, p.79; Petrie, W. M. F. Wisdom of the Egyptians, London, 1940, p.16. But after this date many authors like Neugebauer, O. and Parker, R. A. in their Egyptian Astronomical Texts (EAT) get to the information that the decans are both groups of stars and constellations. Some constellations cover more than one decan; on the other hand there are decans following a constellation.

${ }^{58}$ Pyramid texts are group of magical spells and ritual utterances inscribed on the walls of the burial chambers of kings' pyramids from the late $5^{\text {th }}$ Dynasty onward, and later in the tombs of the non-royal elite. 
form on astronomical monuments after the primary 36 decans. Like the primary decans, the triangle ones are accompanied by stars, deities, figures and infrequently, legends. ${ }^{59}$ Both ordinary and triangle decans are included, with the triangle decans separated from the ordinary decans by the interposition of the planets.

The hieroglyphic names of the 'Two Turtles' decanal star appeared in the Coffin Texts, which is among the most important discoveries in the field of Archeoastronmy during the Middle Kingdom. It appeared in many forms as: $\square \times, 2 \%$, \& $\xi_{0}$ 'stw var. Stwy, classified as 'Decan 31 b' by some writers (Hannig, 2008). This is the first known astronomical reference to this animal. Literally it is identical to the "two turtles," decan which appeared later during the New Kingdom for the first time in Senenmut tomb and later as part of many other astronomical scenes.

Neugebauer and Parker classified decans in different six major groups with several sub-groups. The main groups (families) ${ }^{60}$ are the Primary Decans and the others are the Triangle Decans of the Epagomenal Days. The sup-groups are six different decanal lists. The differences are not great, consisting mainly of the dropping out of one or two decans and their replacement by others. Those main groups are: Senenmut Family of Decans, Seti I A Family, Seti I B Family, Seti I C Family, Tanis Family and Miscellaneous List. Turtle decan appeared as a Triangle Decan on five of the previous lists, as the following:

\subsection{The Senenmut Family of Decans: ${ }^{61}$}

Turtle appeared on Senenmut, Amenhotep III, Ramesseum A, Ibi, Pedamenope, Montemhet, Roda (very incompletely preserved), Abu Yasin and Harendotes, and Hermopolis B (partly preserved), as $\cong$ Stwy. In Abu Yasin, it repeats; and in Harendotes performed in a column over nsrw and others. In both Pedamenope and Montemhet, 24 Stars appeared in two large turtles; while there are only 4 stars performed in

59 EAT III, p.3.

60 These groups of similar sources are created by modern researchers to make it easy to study decans.

61 It consists of eighteen lists, of which the earliest monument was from approximately 1473 BC., while the latest probably dated back to 246-221 B.C. EAT III, p. 105.
Harendotes between two turtles. For the other monuments' stars omit but have two turtles as accompanying figures.

However, on Ramsses VI C and D, Ramsses VII B (now lost), and Ramsses IX B (now lost) it appeared as $\triangle \rho \mathrm{III}$, without any stars performing, but two turtles accompanied the name. ${ }^{62}$

In this Family, deities Hapy and Duamutef appeared but omitted on Amenhotep III, Ramesseum A, Pedamenope, Montemhet, Abu Yasin, and Harendotes.

\subsection{The Seti I A Family of Decans: ${ }^{63}$}

Turtle appeared on Ramsses VI A and B, Ramsses VII A (now lost), Ramsses IX A, Petosiris and Nekhtnebef, in the form of two different decans Stwy and siAtw as the following:

$=\approx X_{\text {Stwy (always in a column with siAtw }}$

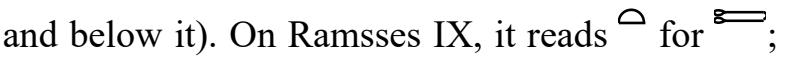
while Petosiris omits the name but has turtles. In this decan, stars omitted, but over two turtles.

$=\square x_{\text {siAtw (always in a column with }}$ Stwy and above it). On Ramsses IX (partly preserved) adds "II ; while on Petosiris, it reads as ○ 2 with an error $\rightleftharpoons$ for $\equiv$; without any stars performing. While on Nekhtnebef, it reads as סू, 64 clearly a misunderstanding of siAtw as SAtw, which then led to Stw, with ${ }^{\ominus}$ for ${ }^{\circledR}$; without any stars represented. Again on Petosiris, for one more time, turtle also appeared $\mathcal{O}_{\text {for }}{ }^{\circ}$ in the Sspt decan.

Accordingly, the order Stwy, siAtw appeared in this way due to the usual practice when doubling names in a column was to put the first decan below its successor. Neverless the possiility remains that the correct order is siAtw, Stwy according to most of the astronomical scenes like Seit I, Ramsses IV and others. ${ }^{65}$ In all those decans of this family, deities are completely omitted.

62 EAT III, p.116.

63 This family consists of eight lists; the earliest was from the Cenotaph of Seti I at Abydos and the latest from the tomb of Petosiris, about 150 B.C. EAT III, p. 118 .

64 EAT III, p. 125.

65 EAT III, p. 125. 


\subsection{The Seti I C Family of Decans: ${ }^{66}$}

Turtle appeared on Seti I, Ramesseum B, Merneptah B, Tausert A and B as Stwy decan; with a single star performing. Also both deities Hapy or Duamutef are represented and figured as Jackal and baboon-headed gods. ${ }^{67}$

\subsection{The Tanis Family of Decans: ${ }^{68}$}

Turtle appeared on Hermopolis A and Esna as $\longrightarrow$ of

$\approx$ Stwy decan, in the form of two large turtles, accompanied by 4 stars. Especially in Hermopolis A, there are seven extraordinary features that appeared. Between decans 1-17 and the body of Nut is a row of figures, usually found under the decans, followed by the planets and a muchabbreviated triangle, consisting only of Stwy with large two turtles, among them a bark with 22 stars, Orion and others. ${ }^{69}$

\subsection{Miscellaneous Lists: ${ }^{70}$}

Turtle appeared in this family on Ramsses VI E as

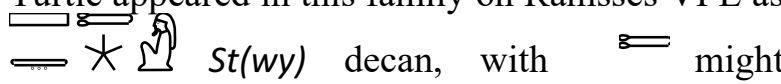
conceivably be an error for $2{ }^{71}$ While on Psusennes, it appeared as o ${ }^{\prime \prime}$ Stwy, ${ }^{72}$ flanked by two turtles; and both deities Hapy and Duamutef represented as Jackal - and baboon headed mummiform gods.

\section{Discussions}

According to the previous lists, Turtles appeared only on five families as a Triangle Decan, accompanied by a variation in the spelling from one family to another; it located as usual among this group of decans that are separated from the internal planets and that of the external planets in the celestial diagrams, and follow both Jupiter and Saturn. These Epagomenal stars are most often

${ }^{66}$ This family consists of seven lists and are much more compact in time than others, ranging as it does only from Seti I tomb (1303-1290 B.C.) to Tausert tomb (1189-1181 B.C.), slightly more than a century. EAT III, p.129.

${ }^{67}$ EAT III, p.147.

${ }^{68}$ Of the ten lists, Tanis is the earliest to be dated; most of it probably belongs to the $26^{\text {th }}$ Dynasty (664-525 B.C.) while the remaining nine are from the GrecoRoman period in Esna C (69-96 A.D.). EAT III, p.140. outside the decanal cycle. They are "auxiliary" decans, close to Sirius and Orion constellations. Conventionally, Stwy follows the constellations Orion, Sothis, and Planet Saturn; while sometimes the two turtles represented joining a heron ( $D A$ planet Venus), like on Harendotes and Hermopolis A. Becker mentioned that in some ancient civilization, turtle was sacred to (Aphrodite) Venus due to its numerous offspring (Becker, 1994). Only on Abu Yasin coffin, decan list gives a clear connection between decans, deities, decanal figures, and civil month labels. Stwy decan is fitting together to the day 6 of the fourth month of prt winter.

The ceiling of Karakhamun's main burial chamber is one of the preserved copies of the main stream of the Senenmut decans family. Only three astronomical monuments are older than Karakhamun in that decan family: Senenmut, Amenhotep III and Ramesseum; while the nearest examples belong to Petamenophis. Spalinger suggested that the astronomical ceiling of the Ramesseum might represent an extended design of Amenhotep III, it is supposed to be a copy of an older object (Spalinger, 1995).

The coffin of Heter has the same Theban provenance, date, and arched form as Soter's family coffins (Seonsaos - Kleopatra Petamenophis). Like the Soter coffin, Heter's has a zodiac inside its arched lid, and this is where the representations of the turtles appear along the side of Nut's arms. On both Petamenophis and Kleopatra, four turtles appeared two on each side of her face, while on Seonaos, Heter and Karakhamon only two turtles appeared on one side of her head.

For a moment, it is possible to determine the precise number of star rows around the turtles in some scenes; most probably there was at least one, and extent to four around some, with one exception is the coffin of Petemenophis, where the four turtles are surrounded by 12 stars. These stars

${ }^{69}$ EAT III, p.148.

70 These four decan lists are very unique ant not belong to any of the main five families, all were incomplete, they were associated by deities who cannot be easily fitting into any of the preceding families. EAT III, p.149.

${ }^{71}$ EAT III, p. 150.

72 EAT III, p.152. 
surrounding turtles in some monuments could form part of larger constellations which are represented in the lower part of the register.

On some monuments, decans and planets of the southern sky, represented each in a single boat, sometimes joint each other in a single boat; or represented next to each other horizontally. But Turtles Decan is never represented riding in a boat in any of the astronomical scenes, conflicting its nature as an aquatic animal. An extraordinary scene, the turtle-decan appeared on Esna Zodiac (pl.1.3) surrounded by four Red Crowns of Lower Egypt and a group of serpentine decans, which is typical to the figure of the turtle in the Hymn to Sobek at Kom Ombo (fig.5).

\section{Figure 5}

Ideogram of the turtle from a Hymn to Sobek at Kom Ombo

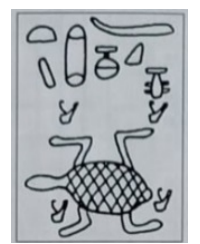

After Guilhou, N. "La constellation de la Tortue, proposition d'identification," fig.9.

Both the two names Stw or Stwy were used to identify the Turtle Decan. In most cases, the names are written as though they were a pair but sometimes as plural. The first name Stw, refers to primary transit decan, ${ }^{73}$ but it is common as a rising decan in the triangle. While the second name Stwy, refers also to a primary transit decan but much more common in the triangle. Restored with high probability in coffin group IV of the Middle Kingdom, it is then found in every subsequent group and family of rising decans, Coffin group $\mathrm{V}$ writes the plural Stw as does Senenmut 's Family. ${ }^{74}$ Notifying that Stwy Decan appeared on some monuments dating back to the Greco-Roman Period as a figure only without a certain written name, like on the temples of Deir el-Haggar, Esna and Dendera; tomb of Karakhamun, and finally some coffins belong to: Kleopatra, Seonsaos, Heter and Petemenophis. The pair of turtles also appeared as determinative for the Stwy Decan only one time on Seti I.

While the name omitted from some New kingdom scenes, which is: Ramsses VI, Ramsses VII, Ramsses IX and Mernptah. Although the turtle determinative 2 appeared a few times accompanied both siAtw and Sspt decans only on those monuments belonging to the Seti I A Family of decans, which could be just a matter of error. Indeed, the outlines of the pair of turtles can be found in the region of the Southern Sky easily. There they always face left, but in Senenmut's astronomical diagram they of course look in the opposite direction, in agreement with its overall iconographic orientation. The most noteworthy feature of this decan is a sequence of the geminate of the animal which always appears as a pair, incorporated into the pattern through periods. The sequence is different in only four instances, Dendera, Deir el-Haggar, Esna temples and Roda, where Stwy performed as a single tortoise. No explanation can be given for this feature, but it is surely not merely decorative, especially since it is repeated with identical frequency in later documents.

The Egyptian artist, when he came to choose the most characteristic feature in which turtle represented, found that he had to show it from above, which is found already in the forms of certain number of the Predynastic slate palettes and the scenes of the later periods till the Greco-Roman Period. That profile position of the turtle was quite usual on most of the monuments, even the nonastronomical ones like magical tools. A rare text on a sarcophagus (Fischer, 1968 and Brunton, 1927) is a kind of sorcery magical formula in favor of the deceased point to that the life of Ra associated with the death of the turtle. In this case it is represented in a rare confusing form with the carapace in profile ( उह गJ) with two pairs of human legs.

The most popular figure which regards representing a turtle seems to be the freshwater turtle more than the desert tortoise. The body of the supposed glyph and art representations is a depressed oval, and the long neck of the Nile softshell turtle, which are the features of the turtles. Nevertheless, that appearance was more associated with the Greco-Roman representations than the Late Period. There is no evidence that the representation of the astral turtles was ever mutilated, as usually happened for amulets and some magical tools. The eyes in particular are most seriously pecked by, in addition to being blinded, the animal was defaced (Fischer, 1966).

${ }^{73}$ EAT III, p.164.

${ }^{74}$ EAT III, p. 165. 
Realistically to the nature of the animal, stippled carapace appeared only on one astronomical scene which is the water clock that dates back to the reign of Amenhotep III. Another solo represenation of the turtle on the coffin of Harendotes, has a special carapace covered completely with horizontal lines. While, the most pupolar design of the carapace is in the shape of a crossed-network, appeared on fourteen scenes, among them are six carapace performed with a line crossed it in the middle, starting from the head and end by the tail of the animal. Although, turtle's carapace appeared plained without any design in eight more scenes. It seems that; the frequently cross-hatched carapace of the turtle has less effect than realistic with the purpose to controling its power.

The majority of decans are usually flanked by the name or the image of a deity that is supposed to be mythologically associated with them. Sometimes the triangle decans are flanked by deities. They usually have a lunar disk on the head, and on the body there are at times stars (sometimes shown as circles) at such points as wrists, elbows, shoulders, navel, knees and ankles. Joining the turtle-decans,

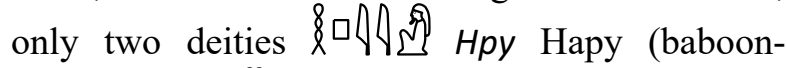
headed) and ${ }_{\text {var. }} \times 10 \_d w A-m w t . f$ Duamutef (jackal-headed), two of the four Sons of Horus, appeared only in three of the previous decan families (Senenmut - Seti I A - Miscellaneous), some with figures and others with the name only, like on Senenmut. Noted, it is a general rule that the monuments of the Senenmut family omit all names and have figures only. We also have to recognize that the main god of evil Seth is never associated with the turtle Decans, as two of the benevolent sons of Horus.

\subsection{Stwy and Nut}

The interior lid of the coffin was analogous to the ceiling of a tomb; decorated with extraordinary zodiacs. These drawings involve a depiction of Nut, along whose sides some astronomical celestial bodies arranged around her, like constellations, and the 24 hours of the day and night. The head of the goddess is over the head of the deceased. Representing Nut laying inside the coffin, symbolically according to Troy, she ready to enfold and hug the deceased in a sexually charged union that donated to the process of resurrection (Troy,

\footnotetext{
75 The sky goddess Nut was probably one of the oldest deities in the Egyptian pantheon.
}

1986). She is oriented west with the southern and northern constellations positioned accordingly. The goddess $\mathrm{Nut}^{75}$ on the ceiling of our tombs, is represented in the most original and prominent feature as stretching from the eastern to the western wall, with her head on the east side, according to the mythological orientation of the burial chamber with the cardinal directions. The matter that is so clear in the cluster of astronomical representations on the tomb of Karakhamunin at Asasif; excluding the tombs of $\mathrm{Ibi}^{76}$ and Petamenophis which were designed according to the Sennmut style. This type of orientation of the goddess became very common in the Ptolemaic and Roman periods.

This image of Nut has an earlier, close pattern in the sarcophagus of Psusennes. Where she is represented with a wig, her body is covered with stars. A similar pattern surrounds other monuments, such as sarcophagi of Harendotes, Kleopatra, Seonsaos, Petemenophis, Heter and later Hermopolis gallery. She is always depicted in anthropomorphic form frontally in the middle of the scene, with rising arms, and her feet are extended as if viewed from above. Her body is generally slender, and sometimes has fatty proportions, fully clothed, and in some cases above her head is a sun-disk represented with streaming solar rays.

Exclusively on four coffins (Kleopatra, Seonsaos, Heter, Petemenophis), a special spot around the head of the goddess Nut chosen to be occupied by the turtle-decan Stwy not any other decans, placed in the direct vicinity of her arms. On Petemenophis coffin, the two turtles to the right of Nut's head are followed by zodiacal sign Capricorn which touching the finger of the goddess, while in the same position on Heter coffin, the pair of turtles followed by a seated crocodile-headed dog holding two knifes, seems to be a kind of demon-guardian. In Dendera (pl.1.5) (Derchain, 1963 and Cauville, 1997), Nut is depicted in profile stretched out over the earth with her feet resting on the eastern horizon and her hands touching the western horizon. She wears a headdress and a long gown and surrounding a group of celestial bodies. The Turtle represents above the Orion and Sirius constellations and diving under the Lunar Boat. While, in Deir el-Haggar, to the right of the curledup Geb, and to the left of Nut's arms, Stwy appeared

\footnotetext{
76 The design of the ceiling has fallen, leaving only the long edges and some other fragments in place.
} 
as a single turtle on a pedestal, followed by a female figured planet Venus, and a heron on a pedestal. We recognize that its iconography is different from that of the other decans around by their predominantly leonine and serpentine iconography.

\subsection{Stwy and the Flood}

The scheme implies that the two turtles are found around either Leo or Virgo, and to the east of the star Sirius. Gutbub believed that some references to the turtle dating from the Greco-Roman Period may located it narrow down Leo (Gutbub, 1979). At that time the rising of the turtles upon the surface of the Nile water or on the sandy islands for long time more than the usual, was strongly linked to the appearance of the star Sirius, the herald of the inundation. That shows the connection between the inundation in the form of Leo and Stwy which is apparent in many zodiacs of this late period.

From China, Korea and other civilizations, tradition there associates the appearance of a cosmic turtle with the story of a great flood (Kelley, 2011). Many archaeologists believe that the Stwy constellation is definitely connected to the beginning of the year and the flood, which links to the zenith of Vega, the brightest star in the constellation 'Lyra. Vega appears in close connection with Sirius, the harbinger of the inundation, when the latter makes its heliacal rise, Vega is set up in the sky since nightfall (Gutbub, 1979; Kaper, 1995 and Guilhou, 2016); a situation which matches well to that of the Stwy usually follows Sothis and Orion on the representations of some astronomical scenes, like Dendara and others. That combination between Sothis and the inundation of the Nile in the form of Stwy, has recently been discussed by Desroches-Noblecourt, who relates the theme to the liminal period of the epagomenal days and the renewal of the year (Desroches-Noblecourt, 1993). A text on Sarcophagi dating back the Middle Kingdom, it personifies the turtle Demon wnm-HwAAt, "the one who eats the decaying bodily fluids", namely the perishable fluids from the body of Osiris, integrated to the fertilizing water of the flood (Gutbub, 1979 and Pantalacci, 1983). In the Egyptian documentation of the Greco Roman Period, turtles have been interpreted as symbols of

77 It is named after its first owner, Comte Odet de Jumilhac. For more information see: Vandier, M. "Le Papyrus Jumilhac," L'Acaémie des inscriptions et the rising Nile and renewed fertility (Malaise, 1991).

Like that Hymn to Sobek at Kom Ombo, another well-preserved cult topographical treatise is the Papyrus Jumilhac, ${ }^{77}$ which also gives us a clear idea about the role that turtle played in controlling the flood. The papyrus which is dated back to late Ptolemaic Period written in Hieroglyphs with occasional Demotic jottings, which pertains to the $17^{\text {th }}$ and $18^{\text {th }}$ provinces of Upper Egypt, it covers with the information that's recorded in the Priesthood Manual but adds a lot more detail and information. The text reads as: "If this place is deprived of its libations, the flood from its cave, the mouth of the turtle remains closed, and there is a year of famine in the whole country" (Gutbub, 1979 and Guilhou, 2016) On it, the turtle also mentioned controls and pours out the flood in its time that fertilizes the land.

\subsection{Spearing turtle}

The turtle is distinguished in the Book of the Dead spell 161, in which it said that: "May Ra live and may the turtle die" (Allen, 1974) This formula was often inscribed onto funerary equipment and tomb walls, and wishing the death of the turtle was quite logical for the Egyptians, as a dangerous animal dwell in the shadowy waters, and as one of the enemies of the sun god Ra. Priskin has another cosmic reading for the formula as its title abilities to make an opening in the sky and explain the position of the constellation of the two turtles (Priskin, 2019). During the Middle Kingdom, when the sun was rising at dawn on the eastern horizon at the time of the winter solstice, the two turtles were at once setting in the west, the land of the dead. This was of course the period when each year the sun, after the days of the longest nights, was reborn, as it again started its journey northwards when seen at its time of rising on the eastern horizon. The magical formula discusses its useful effects on the deceased by frequently stating that $\mathrm{Ra}$ lives and the turtle dies, or the sun emerges in the east, and the two turtles go under in the west. Not only as a triangle decan is the obtainable representation of the Turtle on the astronomical scenes, but also it occupies a part as a creature of evil symbolizing death and darkness, probably due to its water-based reality, it was believed to inhabit

Belles-Lettres, tome 89.2, Paris, 1945; Vandier, J. Le Papyrus Jumilhac, Centre National de la Recherche Scientifique, Paris, 1962. 
the foggy waters of the Underworld, waiting to impede the nightly progression of the Sun God's bark. As a part of the rectangular zodiac at the Hypostyle Hall of Dendera Temple (fig.6), a scene dating back to the Roman Period represent the sun god $\mathrm{Ra}$ traveling across the sky in his solar bark. Near the bow, a falcon-headed god is spearing a turtle, symbol of the evil spirited god Seth.

Another scene belongs to the astronomical scene from the tomb of Petosiris, as a part of the Northern Constellation, a human falcon-headed figure is seen using a spear attacked a turtle in front of him (fig.7), located in front of Croc constellation in the form of a crocodile. This standing man with raised arms is identical to the same figure of the so called Man constellation ${ }^{78}$ in Senemut, Amenhotep III and other scenes, represented spearing the crocodile. The scene is about the ceremony of slaying of the turtle by Horus which occupied a part of temples dating from the Greco-Roman Period. During this Period turtle was thought of among some other creatures as evil enemies to be killed in order to defeat the evil they represented being killed (Durchain, 1964 and Taylor, 2016).

\section{Figure 6}

A part of the rectangular zodiac at the Hypostyle Hall of Dendera Temple

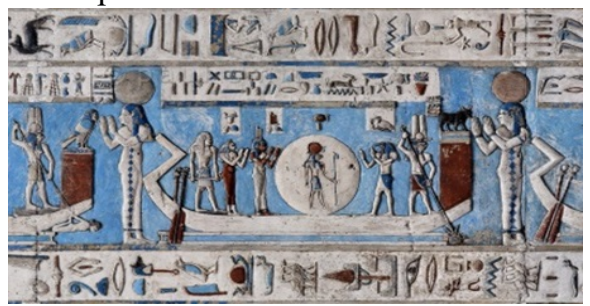

cf. https://www.pinterest.com/Graeco-Roman-Egyptian Art [Accessed on 3 February 2020]

\section{Figure 7}

A reconstruction of the celling of Petosiris according to Daressy's description.

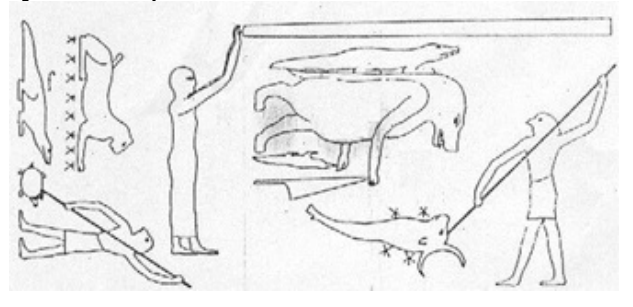

78 For more information about this constellation read: Etz, D. V. "A New Look at the Constellation Figures in the Celestial Diagram," JNES, vol. 34, London, 1997, pp.143-161.

${ }^{79}$ PL, p.880. cf. EAT III, fig. 15 .

Starting from the Ptolemaic Period, turtle was regarded as a demonic creature or 'Sethian animal'

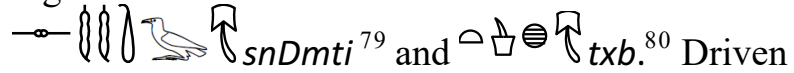

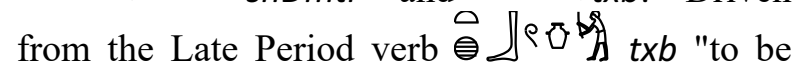
steeped in" or "to immerse" 81 refers to its nature. Possibly because it was seen to dive down into the dark waters of the Nile, where Ra sailed at night and met all the Sethian forces. The turtle came to symbolize enemy of $\mathrm{Ra}$ and could be identified with Apophis and is included among the creatures to be destroyed for Maat to be restored (Sauneron, 1964). Although turtle as Seth is not definitely named in these reliefs, it is linked to him as an evil creature that had to be killed.

Apophis is the serpent of chaos, the enemy of $\mathrm{Ra}$ and of the dead. In the Books of the Underworld, the struggle between Ra and Apophis, who tries to stop him in his journey through the underworld; at dawn Ra or his crew, destroy Apophis so that Ra can rise and shine over the earth. The texts describing the hours of the day often refer to this victory over Apophis. In the $4^{\text {th }}$ hour, the uraeus burns Apophis, and a spear is put in his head. During the $2^{\text {nd }}$ Hour of the Day in the Amduat, when god sails in the sky, victorious over foes and this causes gods and people to rejoice, when Nefertum is shown spearing a turtle, while Ra as a child sits in his barque. $^{82}$

\section{Figure 8}

Empror Titus harpoons the turtle, temple of Khnum, Esna. Roman Period.

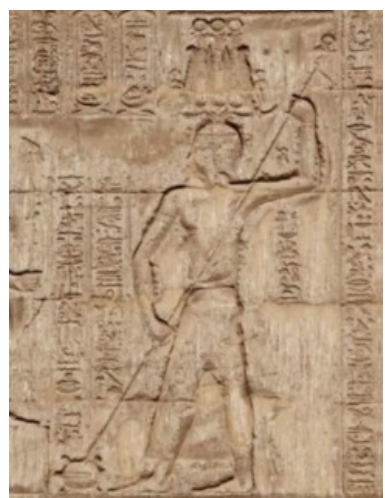

Taylor, I.R. Deconstructing the iconography of Seth, Fig. 9.95.
80 PL, p. 1150.
${ }^{81} L E$, vol.2, p.218.
${ }^{82}$ LTE, tome 3, p.215. (2); PL, p.927. 


\section{Figure 9}

Seth with a turtle and a lizard. Stela no.1935-200-445 in Hamburg Museum - Late Period

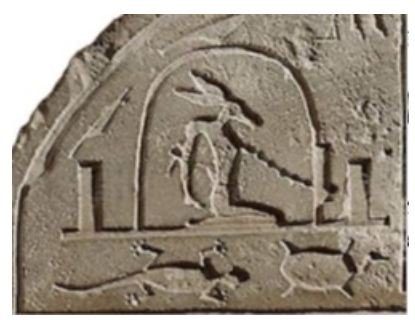

cf. Taylor, I.R. Deconstructing the iconography of Seth, Fig. 9.98.

During the Greco Roman Period, many texts are connected with to the same matter. Many texts in Edfu temple are referring to the turtle as a creature who settles in the water, like: Hqt $m$ tbtb snDmti $n$ $w n$ 'the turtle is slain and Seth does not exist', ${ }^{83} \mathrm{txb}$ $d r$ ti 'the turtle is driven away. ${ }^{84}$ While sometimes it is named as $\mathrm{O}$ o Hmty 'coward', ${ }^{85}$ a common designation of Seth who can be shown as a tortoise. Another text in the library of the same temple begins as 'felling Apophis for his father Ra in the $12^{\text {th }}$ hour of the day. ${ }^{186}$

In the 'killing the turtle' texts, the king represented as a mythical $X r y-x t$ 'epithet of Horus', 87 a warrior god whose special weapon is a club such as Montu or Horus of Letopolis. A text in Edfu reads:

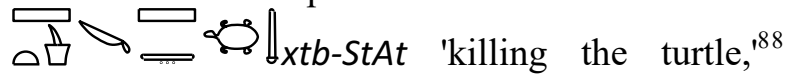
Horus says to the king: my knife is stuck in your foes'. ${ }^{89}$ Another text from the same temple, Horus says: 'I make a shield of copper around the temple' (Walle, 1953), ${ }^{90}$ it is a kind of shield that was used to give protection to the temple. This is a turtle slaying text and it seems that the killing of the turtle, protected by his carapace can be rewarded by a shield of copper, perhaps an allusion to the turtle shell used as defensive armour. The same scene was performed in many other Greco-Roman period temples like Philae, Dendera and Esna (fig.8), where the king represented ritually harpoon the turtle. The battle of the king against the enemies of Egypt, is the reflection of another fight transposed into the cosmological sphere and engraved in the scene of spearing the turtle - enemy of Ra.

\footnotetext{
${ }^{83}$ LTE, tome 3, p.4 (14).

${ }^{84}$ LTE, tome 7, p.159 (5).

${ }^{85}$ LTE, tome 3, p.4 (13); PL, p.650.

${ }^{86}$ LTE, tome 3, p.349 (13); PL, p.137.
}

\section{Figure 10}

Dakhla Oasis, Tomb of Petosiris, Room I, the North End of the East Wall

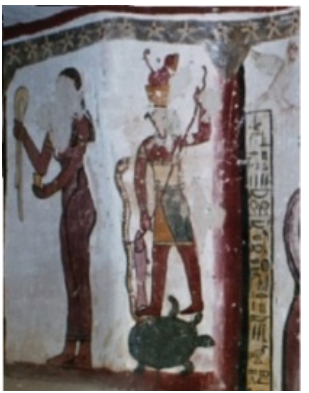

cf. Venit, M. S. Visualizing the Afterlife in the Tombs of Greco-Roman Egypt, Cambridge University Press, London, 2016, pl.xxviii

The researcher does not agree with Hornung who suggests that, although ritual scenes of 'Spearing Apophis' arise only in Ptolemaic and Roman temples (Hornung, 1956), because there are various actions against Apophis that come down from earlier sources. Additional form of beating the turtle, and as a part of the traditional representation of the Nile and its creatures in the private tombs, turtle sometimes performed beneath a skiff in which the deceased is fowling. Only one case in a daily life scene dating back to the $19^{\text {th }}$ Dynasty (fig.11) (Säve-Söderbergh, 19656), the deceased is representing harpoon the turtle as a personification of evil in the swamps. It is considered the earliest known among these kinds of harpooning scenes.

\section{Conclusion}

This study identifies specific source for the turtle figures on some distinctive astronomical scenes or "zodiacs" which decorated some monuments (temples, tombs, coffins, gallery, water clock, and others), are shown a complete relation with the depictions of such animal and its representation in these kinds of scenes; while the best examples of turtle figures have been found on the ceiling of the temples, tombs, and coffins. It forms widespread renovations in the Late and Greco-Roman periods. Identifying the connections between all of those monuments which reveal the kind of editions of much earlier texts and scenes which came about it. Equally evidently, it is the strict absence of this type of iconography of turtle from drawings found

$87 \mathrm{~Wb}$ III, p.395.

${ }^{88}$ LTE, tome 5, p.168 (14); PL, p.778.

${ }^{89}$ LTE, tome 4, p.151 (3); PL, p.1034.

${ }^{90}$ LTE, tome 7, p.182 (1-2). 
in monuments and inscriptions of much earlier periods, especially during the Middle Kingdom. Turtles dwelled the sky by the Early New Kingdom, and acquired a traditional shape represent the animal form itself, not comparable to the other animals like for example serpents, which appeared in variety of shapes (winged, erected, coiled, even if they are represented as a human figure (with human heads, arms, legs, or all together). We now have a detail picture not only of the figure of the turtles and the place of their practice, but also the apparatus they used to conquer the astronomical scenes and be one the most popular creatures used to decorate them. The article also shows that considerable role turtle played in ancient astronomy.

\section{References}

Abd el-Salam, A. (1938). Rapport sur les fouilles du Service des Antiquités à Abou-Yassin (Charquieh), Annales du Service des Antiquités de l'Égypte, $38,609-22$.

Allen, T. G. (1974). The Book of the Dead or Going Forth by Day-Ideas of the Ancient Egyptians Concerning the Hereafter as Expressed in their Own Terms, Studies in Ancient Oriental Civilization, vol. 37, University of Chicago Press., Chicago.

Anderson, J. (1898). Zoology of Egypt, vol.1, London.

Antoniadi, E.M. (1934). L'astronomie Egyptiennedepuis les temps les plus reculés jusqu'à la fin de l'époque Alexandrine, Gauthier-Villars, Paris.

Becker, U. (1994). The Continuum Encyclopedia of Symbols, Continum, London.

Bishop Isidore of Seville (2006). The Etymologies of Isidore of Seville, translated by Stephen A. Barney and others, Cambridge University Press, New York.

Borchardt, L. (1920). "Die Altägyptische Zeitmessung," Die Geschichte der Zeitmessung und ser Uhren, band 1 , Berlin.

Brugsch, H. (1883). Thesaurus Inscriptionum Aegyptiacarum, band 1: "Astronomische und Astrologische Inschriften Altaegyptischer, Dnkmaeler." J.C. Hinrich' Sche Buchhanlung, Leipzig.

Brugsch, H. (1880). "Ueber ein neu entdecktes astronomisches Denkmal aus der thebanischen Nekropolis," Z̈̈S, 14, Leipzig.

Brunton, G. and Engelbach, R. (1927). Gurob, British School of Archaeology in Egypt, London.

Budge, E. A. W. (1904). British Museum, Guide to the first and second Egyptians rooms, London.

Carr, A. F. (1952). Handbook of Turtles, Cornell University Press, New York.

Cauville, S. (2001). Dendera - Le fonds hiéroglyphique au temps de Cléopâtre, Cypele, Paris.
Cauville, S. (1997). Le temple de Dendara, Les chapelles osiriennes, X/II, Le Caire, pl.260.

Chassinat, É. (1928). Le Temple d'Edfu, Mémoires publiés par les Members de la Mission archéologique francaise au Caire, tome 20, Institut Francais d'Archéologie Orientale, Le Caire.

Christoph, S. and Willi, S. (2008). "The Egyptian Tortoise, Testudo kleinmanni Lortet, 1883 in Libya," Salamandra, vol.44, no.3, Rheinbach, pp.141-152.

Cirlot, J. E. (2002). A Dictionary of Symbols, translated by Sage, J., Courier Dover Publications, London, p.353.

Daressy, G. (1902). "Tombeau Ptolémaique à Atfieh," ASAE, vol.3, Cairo, pp.175-9.

Daressy, G. (1900). "Une ancient liste de decans Égyptiens," ASAE, tome1, Le Caire, p.79.

Darnell, J. C. (2004). The Enigmatic Netherworld Books of the Solar-Osirian Unity, Academic Press Fribourg Vandenhoeck and Ruprecht Göttingen, Zürich, pp.374-424.

De Buck, A. (1961). The Egyptian Coffin Texts, The University of Chicago Press, Chicago vol.5, p.30, spell 368.

De Morgan, J. (1895). Kom Ombos Catalogue des Monuments d'inscriptions, tome 1, Vienne.

Deines, H. and Grapow, H. (1959). Wörterbuch der ägyptischen Drogennamen, Grundriss der Medizin der alten Ägypter VI, Berlin, pp.508-9.

Delvaux, L. (2014). "Grenouilles et crocodiles : Objets et pratiques magiques dans l'Egypte du Moyen Empire," Bulletin de l'Académie royale des Sciences d'Outre-Mer, tome 60 (3-4), Belgium, p.403.

Derchain, P. (1963). "La Pêche de L'oeil et les Mystères d'Osiris a Dendara," RdE, tome 15, Paris, p.24 and fig.6.

Desroches-Noblecourt, Ch. (1993). "Le zodiaque de pharaon," Archeologia, vol. 292, Paris, pp.39-42.

Dorman, P. (1991). The tombs of Senenmut- the Architecture and Decoration of tombs 71 and 353, Metropolitan Museum of Art, New York, 138-146.

Durchain, P. (1964). "A propos d'une stele magique du musee Kestner. A Hanovre," RdE , tome 16, Paris, p.20.

Durrell, G. (1953). The Overloaded Ark, Penguin Books, p.221.

Erman, A. and Grapow, H. (1962). Wörterbuch der Aegyptishen Sprache, 5 vols, Hinrichs' sche Buchhandlung, Leipzing.

Etz, D. V. (1997). "A New Look at the Constellation Figures in the Celestial Diagram," JNES, vol. 34, London, pp.143-161.

Faulkner, R. O. (1981). A concise dictionary of Middle Egyptian, Griffith Institute - Ashmolean Museum, Oxford. 
Faulkner, R. O. (1977). The Ancient Egyptian Coffin Texts, Aris and Phillips, Warminster, vol.1, spell 310 , p.228, no.2.

Fischer, H. G. (1968). Ancient Egyptian representation of turtles, The Metropolitan Museum of Art Papers, paper no.13, New York.

Fischer, H. G. (1966). "Egyptian Turtles," Bulletin of The Metropolitan Museum of Art, vol.24, New York, pp.193-200.

Fischer, H. G. (1962). "The cult and nome of goddess bat," JARCE, vol.1, Cairo.

Friedman, R. F. (2011). "Hierakonpolis," Before the Pyramids - The origins of Egyptian civilization, Oriental Institute Publications, vol.33, Chicago, p.35.

Hannig, R. et Vomberg, P. (1999). Wortschatz der Pharaonen in Sachgruppen, Verlag Philipp von Zabern, Mainz, table 1 and p.257.

Haynes, R. D. and others (2000). Science across cultures: The History of Non-Western Science vol.1: Astronomy across Culture, Springer-Science + Business Media, USA.

Hornung, E. (1956). "Chaotische bereiche in der geordneten Welt," ZÄS, band 81, Berlin.

Gabra, S. (1939). "Fouilles de 1' univeriste Fouad El Awel a Tuna El-Gebel", ASAE, tome 39, Le Caire, pp.491-2.

Gadré, K. (2008). Conception d'un modèle de visibilité d'étoile nu, Application ä l'identification des décans égyptiens, Université de Toulouse, Toulouse.

Guilhou, N. (2016). "La constellation de la Tortue, proposition d'identification," dans Proceedings of the Tenth International Congress of Egyptologists, University of the Aegean, Rhodes, 22-29 May 2008, OLA 241, Leuven, pp.1131-1142.

Gundel, W. (1936). Dekane und Dekansternbilder : ein Beitrag zur Geschichte der Sternbilder der Kulturvölker, Studien der Bibliothek Warburg, Glückstadt and Hamburg, Darmstadt, pl.9.

Gutbub, A. (1979). "La tortue - animal cosmique bénéfique à l'époque ptolémaique et romaine," Hommages à la mémoire de Serge Sauneron, vol. I: Egypte pharaonique, Bibliothèque d' Etude 81, Le Caire, pp.391-435.

Ihsan, H. (2010). Abd al-Rahman al-Sufi and his book of the fixed stars: a journey of re-discovery, Ph.D. Thesis, James Cook University.

Ikram, S. (2015). Divine Creatures - Animal Mummies in Ancient Egypt, The American University in Cairo, Cairo.

Kadish, G. E. (1968). "Reviewed work: History and Chronology of the Eighteenth Dynasty of Egypt: Seven Studies, Donald B. Redford," JARCE, vol.7, Cairo, 133.

Kaper, O.E. (1995). "The astronomical ceiling of Deir el-Haggar in the Dakhleh Oasis," JEA, 81, London.
Kathryn A. B. (1999). "Armant," Encyclopedia of Archaeology of Ancient Egypt, Routledge, London.

Katja G. (2008). Crowns in Egyptian Funerary Literature. Royalty, Rebirth and Destruction, Griffith Institute, Oxford.

Keller, G. (1913). "Skorpione," Die Antike Tierwelt, band 2, Leipzig.

Kelley, D. H. and Milone, E. F. (2011). "The Descent of the Gods and the Purposes of Ancient Astronomy," Exploring Ancient Skies: An Encyclopedic Survey of Archaeoastronomy, New York.

Kenton, E. (1928). The Book of Earths: the Egyptian universe, (Online edition), Forgotten Books, Available at Http://www.forgottenbooks.org. [Accessed on 2 July 2019].

Kirkpatrick, D. T. (Mars/April 1992). Radiated Tortoise, Reptile and Amphibian Magazine, Pennsylvania, 18-24.

Kitchen, K. A. (1993) Ramesside Inscriptions Translated and Annotated, Chichester: WileyBlackwell, Oxford, vol.3.

Klotz, D. (2012). Articulata Forma Dei. A Cosmic Epithet from Esna and Medinet Habu," ENIM, 5, Archéologie des Sociétés Available at http://recherche.univ-montp3.fr/egyptologie/enim/. [Accessed on 7 November 2020],

Kuhlmann, K. P. (1983). Das grab des Ibi, Obergutsverwalters der Gottes-gemahlin des Amun (Thebanisches Grab Nr. 36), Mainz am Rhein: P. von Zabern, Kairo.

Leblance, Ch. et Nelson, M. (1976). "Le Clepsedre de Karnak," Catalouge de l'exposiyion: Ramses le Grand, Paris, p.139.

Lepsius, R. (1849). Die Chronologie der Aegypter, Nicolaische Buchhandlung, Berlin, pp.68-69, 89, 105 .

Lesko, L. E. (2004). A Dictionary of Late Egyptian, second edition, Brown University, USA.

Loveridge, A. and Williams E. E. (1957). "Revision of the African tortoises and turtles of the suborder Cryptodira," Bulletin of the Museum of Comparative Zoology, vol.115, no.6, The Museum of Comparative Zoology, London, p.163 and 557.

Lull, J. and Belmonte, J. A. (2006). "A firmament above Thebes: Uncovering the constellation of Ancient Egyptians," JHA, vol.xxxvii, Science History Publications Ltd, London, p.11.

Lull, J. and Belmonte, J. A. (2009). "The Constellations of Ancient Egypt," In: Ruggles C. (eds) Handbook of Archaeoastronomy and Ethnoastronomy, Springer, New York, p.171.

Macnoughtan, B. (1932). A scheme of Egyptian chronology, Luzac and Co., London, pp.221-6.

Maeder, S. (2011). "The Big Dipper, Sword, Snake and Turtle: four constellations as indicators of the Ecliptic Pole in Ancient China?" In Nakamura, T. Orchiston, W., Sôma, M., and Strom, R. (eds.), 
Mapping the Oriental Sky. Proceedings of the Seventh International Conference on Oriental Astronomy, National Astronomical Observatory of Japan, Tokyo.

Malaise, M. (1991). "Les animaux et la pot d'Harpocrate: Contributional' iconographiedu fils d'Isis," Bulletin de la Societe Francaise d'Egyptologie, tome 122, Rome, pp.13-35.

Mitchell, A. and Simon M. S. (January 2001). "Salmonella in Reptiles Mark," Seminars in Avian and Exotic Pet Medicine, vol.10, no.1, Philadelphia, pp.25-35.

Montet, P. (1951). La nécropole royale de Tanis, vol. 2: Les constructions et le tombeau de Psousennès à Tanis, Jourde et Allard, Paris, pp.119-20.

Neugebauer, O. and Parker, R. A. (1969). Egyptians Astronomical texts, 3 vols., Brown University Press, London.

Pantalacci, L. (1983). "Wnm-HwAAt: Genèse et carrière d'un génie funéraire," BIFAO, 83, p.306.

Parker, R. A. (1950). The Calendars of Ancient Egypt, Studies in Ancient Oriental Civilization, no.26, Oriental Institute of the University of Chicago, Chicago, pl.3.

Petrie, W. M. F. (1940). Wisdom of the Egyptians, London.

Pogo, A. (1936). "Egyptian water clock," Isis, vol. 25, Brussels.

Polo, M. (2014). "A Bright Night Sky over Karakhamun: the Astronomical ceiling of the main burial chamber in TT 223," In: Pischikova, E. Tombs of South Asasif Necropolis, Thebes, Karakhamun (TT 223) and Karabasken (TT 391) in the twenty-fifty Dynasty, The American University in Cairo Press, Cairo.

Priskin, G. (2019). "The Constellations of the Egyptian Astronomical Diagrams," Égypte Nilotique et Méditerranéenne, tome 12, Montpellier, p.158.

Relek, J. and Ernest A. (2003). "Ancient Egyptian Astronomy: Ursa Major- Symbol of Rejuvenation," Archaeoastronomy, vol.17, Austin, p.67.

Riggs, C. (2006). "Archaism and Artistic Sources in Roman Egypt. The Coffins of the Soter Family and the Temple of Deir el-Medina," Bifao, tome 106, Institut français d'archéologie orientale, Le Caire, pp.316-7.

Riggs, C. (2005). The Beautiful Burial in Roman Egypt: Art, Identity and Funerary Religion, Oxford University Press, New York, pp.281-3.

Rittner, D. and McCabe, T. L. (2004). Encyclopedia of Biology, Facts on File: Library of World History, New York, p.290.

Sauneran, S. (1969). Le Temple d' Esna: tome 4, IFAO, Le Caire, no.418.

Sauneron, S. (1964). "Remarques de philologie et d'étymologie," BIFAO, tome 64, Institut français d'archéologie orientale, Le Caire, pp.1-2.
Säve-Sőderbergh, T. (1956). "Eine ramessidische Darstellung vom Töten der Schildkröte," Mitteilungen des Deutschen Archäologischen Institute, Abteilung Kairo, band 14, Wiesbaden, pp.175-180.

Sloley, R. W. (1931). "Primitive Methods of Measuring time," JEA, vol.17, The Egypt Exploration Society, London, p.174.

Sloley, R. W. (1968). "Science," The legacy of Egypt, Oxford, p.78.

Spalinger, A. J. (1995). "Month Representations," Chronique d'Égypte, tome 70, no.139-40, Brussels, p. 115 .

Stewart, D. (2010). Conservation and Innovation: The Zodiac in Egyptian Art, Master Dg. Emory University.

Stookey, L. L. (2004). Thematic Guide to World Mythology, Greenwood Press, USA, p.15.

Taube, K. (2012). "The Classic Maya Temple: Centrality, Cosmology, and Sacred Geography in Ancient Mesoamerica," Heaven on Earth Temples, Ritual, and cosmic Symbolism in the Ancient World, Oriental Institute of the University of Chicago, Chicago, p.91.

Taylor, I. R. (September 2016). Deconstructing the iconography of Seth, Ph.D. Thesis, University of Birmingham, College of Arts and Law, p207.

Toomer, G. J. (1972). "Mathematics and Astronomy," The legacy of Egypt, Oxford University Press, Oxford.

Troy, L. (1986). Patterns of Queenship in Ancient Egyptian Myth and History, Uppsala, p.46.

Vandier, M. (1945). “Le Papyrus Jumilhac,” L’Acaémie des inscriptions et Belles-Lettres, tome 89.2, Paris.

Vandier, J. (1962). Le Papyrus Jumilhac, Centre National de la Recherche Scientifique, Paris.

Veiga, P. A. S. (2009). Health and Medicine in Ancient Egypt: Magic and Science, Hadrian Books, Oxford, p.51.

Venit, M. S. (2016). Visualizing the Afterlife in the Tombs of Greco-Roman Egypt, Cambridge University Press, London.

Vivian E. R. (1923). Fixed Stars and Constellations in Astrology, London, pp.50-1.

Wagner, M. (2018). "New Research in the Tomb of Ibi (TT 36)," Thebes in the Forst Millenium BC: Art and Archaeology of the Kushite Period and Beyond, GHP Egyptology, vol.27, London.

Walle, B. Van de (1953). "La tortue dans la religion et la magie égyptiennes," La nouvelle Clio, tome 5, Brüssel, 173-89.

Wilson, p. (1997). A Ptolemaic Lexicon: A Lexicographical Study of the Texts in the Temple of Edfu, Leuven. . 